\title{
STRATEGIC CHOICES IN PLURALIST AND UNITARIST EMPLOYMENT RELATIONS REGIMES: A STUDY OF AUSTRALIAN TELECOMMUNICATIONS
}

\author{
PETER ROSS and GREG J. BAMBER*
}

\begin{abstract}
Using interview data collected between 1992 and 2009, the authors explore how deregulation of the Australian telecommunications sector and re-regulation of the labor market affected employment relations (ER) strategies at Telstra, Australia's former telecommunications monopoly. Labor market re-regulation reversed much of the previous institutional support for union activity, and unions struggled to adjust to this changed institutional context. Telstra's ER strategies included large-scale downsizing and outsourcing. It moved dramatically toward unitarist (anti-union) ER approaches, with a shift away from collective bargaining toward individual employment contracts. This history raises a more general question of the extent to which employers make strategic ER choices autonomously and the extent to which such choices reflect the influence of the national institutional context. The authors conclude that while the changing institutional context-in this case, primarily government regulation-facilitated Telstra's strategic choices, management ideology was an important intervening variable in determining such choices.
\end{abstract}

$\mathbf{E}$ arlier research examined the global shifts toward the deregulation and privatization of telecommunications markets across industrialized market economies in the 1990s (Katz 1997). That path-finding analysis identified a "market-driven restructuring" approach in some countries, in con-

*Peter Ross is a senior lecturer at Griffith Business School, Griffith University, Brisbane, Australia. Greg J. Bamber is Professor and Director of Research, Department of Management, Monash University, Melbourne; Adjunct Professor, Griffith University, Australia; and Visiting Professor, Newcastle University, England. An early stage of this research was funded by the Australian Research Council. The authors also thank Daniel Dwyer and William Mansfield for helpful comments on earlier drafts of this paper.

Although the identity of respondents is withheld in accordance with confidentiality undertakings, further details on the data collection process and findings underlying the conclusions in the paper are available from the authors via e-mail: p.ross@griffith.edu.au or GregBamber@gmail.com. trast with a "labor-mediated restructuring" approach in others. Whereas Anglo-Saxon liberal market economies, including that of Australia, focused on cost-cutting and laborshedding strategies, the coordinated market economies of continental Europe tended to have more cooperative employment relations (ER) systems.

This article examines the restructuring and associated ER strategies of the telecommunications company Telstra, which developed as Australian federal governments ${ }^{1}$ deregulated the industry and re-regulated the labor market. The restructuring of the Australian telecommunications sector is an

\footnotetext{
${ }^{1}$ Australia has governments at federal, state, and local levels. Henceforth, however, when we refer to governments or elections or industrial relations jurisdictions in this article, these are all at the federal level, for it is generally at this level that the product and labor markets for telecommunications are regulated.
} 
interesting case. Our findings reveal certain similarities to the experiences of other Anglo-Saxon countries, but also interesting contrasts. Telecommunications have long played a key role in Australia's political economy, and Telstra was privatized later than the telcos (telecommunications companies) in the United Kingdom and New Zealand. Management ER strategies at Telstra also did not parallel the developments at other telcos, such as Telecom New Zealand, which engaged in anti-union strategies immediately after privatization (Ross 2002). Rather, in the early 1990s, Telstra tried to introduce a pluralist "participative approach" with the unions, before shifting to a unitarist antiunion approach later in the decade.

Our research question is how much autonomy was Telstra management able to exercise in making strategic ER policy choices? That is, did Telstra engage in idiosyncratic behavior that fundamentally differed from that of other companies during this period, or did changing external circumstances (including the shifting agendas of successive Australian governments) precondition Telstra management's ER strategies and result in the introduction of ER policies that merely mimicked those being implemented by comparable companies?

\section{Research Methods}

This article was inspired and facilitated by an international research project on telecommunications (Katz 1997). The data collected in Australia included the results of more than 50 semi-structured interviews that were conducted with a wide range of people during the period 1992-2009. These interviews explored the changing nature of Telstra's ER practices in the face of deregulation and privatization. Interviewees included past and present Telstra managers and union representatives who were involved with Telstra. Many interview transcripts were analyzed using the NVivo qualitative data analysis software. These software tools allow researchers to analyze larger amounts of qualitative data than they could using simple manual techniques (Gibbs 2002). Most interviewees, particularly those still associated with Telstra, participated on the basis of anonymity and confidentiality. ${ }^{2}$

One drawback of interviews as a research technique is that what people say may be at cross-purposes with what they do (Gillham 2000:13). Interviewees have beliefs and prejudices that influence their perceptions of events and issues. Corporate loyalty or discipline may induce managers to promote company policies, and concerns about their career prospects may constrain their frankness. For example, in the present study, we found that former Telstra managers tended to be more critical of the company's policies than were current managers. Bearing in mind this challenge, we adopted a triangulation approach, comparing interview data and other information from former and current Telstra managers with that from union representatives and other informants. These data were supplemented by direct observations, company reports, union documents, and other available sources. The latter include analyses of Telstra's collective agreements and decisions of the Australian Industrial Relations Commission (AIRC). The data were also compared with similar interviews that were conducted with telco managers and union representatives in Europe (Ross 2006, 2008) and New Zealand (Ross 2002). This helped us to compare the Australian situation with international trends.

\section{Unitarism, Institutional Change, and Strategic Choice}

A unitarist approach implies that workers should have allegiance to only one authority-usually management. Under this approach, any other allegiances by workers, for example, to a union or other institution, is seen as detracting from their commitment to the employer. This approach confers legitimacy on managerial authority and treats unions as unnecessary "third parties" whose presence upsets the "natural order" of the firm (Fox 1974). A pluralist approach, in contrast, recognizes that firms are made up of "sectional groups whose interests may

\footnotetext{
${ }^{2}$ University ethics protocols bar disclosure of either the names or the positions of interviewees.
} 
coincide or may conflict with rival sources of leadership and attachment" (Geare et al. 2006). The "market-driven restructuring" approach indentified by Katz (1997) in the telcos of the Anglo-Saxon countries in the first half of the 1990s not only focused on cost-cutting and downsizing strategies, but also was associated with shifts toward unitarist approaches to ER.

Why did the telcos in these countries react to deregulation in this way? Resource dependence and contingency theories suggest that firms develop strategies and processes that best fit changing external conditions as they adapt to new contexts (Katz et al. 2003:574). This suggests that the similar types of economic-rationalist policies implemented by these Anglo-Saxon countries created an institutional context that fostered a marketdriven restructuring approach. DiMaggio and Powell (1983) discussed how changing political and regulatory institutions may "coerce" firms into adopting similar strategies. For example, a reduction in institutional support for unions or collective bargaining is likely to influence whether firms engage in union avoidance or union collaboration strategies (Vickerstaff and Thirkell 2000). Mimetic and normative factors may further induce firms to adopt practices that are seen as legitimate in specific markets (DiMaggio and Powell 1983). An implication is that firms may converge toward organizational forms and ER strategies that seem to suit a particular sector, such as telecommunications (Hannan and Freeman 1989; Frumkin and Galaskiewicz 2004:286).

This then begs the question, to what extent do changing institutional constraints tend to limit the potential of such firms to make autonomous strategic choices and engage in alternative strategies? (See Hyman 1987; Whittington 1988; Child 1997.) Sako and Jackson (2006) considered this question by examining the impact of local ER institutions on management decision-making at the telcos in Germany and Japan. This allowed them to compare how different national institutions influenced firms' behavior. They found that firms developed ER practices that were not consistent with the general institutional practices of the countries concerned, leading them to conclude that changes in telco management and union strategies in Germany and Japan did not merely reflect conformity with prevailing institutional norms (Sako and Jackson 2006). This implies that the telcos exercised a degree of strategic choice. Van Kranenburg and Hagedoorne (2008) also concluded that continental-European telcos were exercising different strategic choices as they restructured their firms to enter and expand into new product and geographical markets.

A limitation of much of the above theory is its implication that firms' policy-makers will act as economic rationalists when considering strategic alternatives. As Dean and Sharfman noted, firms do not always engage in economically rational strategic decisionmaking processes. Rather, either policymakers can use all resources and information at their disposal to make economically rational strategic choices-a process termed procedural rationality-or they can make decisions on the basis of self-serving political behavior (1996:370). Child also linked strategic choice and decision-making to "the active role of leading groups who have the power to influence the structures of their organizations through an essentially political process" (1997:43). Geare et al. concurred that management ideology is an important factor in ER and linked contemporary "American-style" HRM strategies to unitarist perspectives (2006:1191). Theories based on rational economic behavior, therefore, may fail to explain the behavior of politically and ideologically driven executives.

This article builds on the earlier marketdriven restructuring approach identified by Katz (1997) by considering the role and influence of executives and their ideological preferences in the strategic choices made at Telstra. These choices include Telstra's relationship with the unions in a changing institutional context, as Australian governments deregulated and privatized telecommunications.

The several stories that compose our narrative-deregulation of the telecommunications industry, changes in the government's ER stance, restructuring of the telecommunications sector, actions by management and 
the unions-are best told separately before they are considered together. Accordingly, in recounting these events, we reset the clock several times. To help readers synthesize the multiple series into one, we provide a roughly linear chronology of all key events in Table 1.

\section{Telecommunications Deregulation in Australia}

Service provision to remote areas of Australia must overcome logistical problems due to the country's large geographic size (it is an island continent) combined with its relatively small population (about 22 million people). Telstra's universal service obligations require it to provide customers with reasonable access to telecommunications services throughout Australia. Proposals to privatize Telstra aroused widespread opposition, including from people living in remote areas, based on concerns that privatization would induce Telstra to accord a lower priority to less profitable or uneconomic remote services.

Left-wing factions of the Australian Labor Party (ALP) and the unions were opposed to privatization not only on ideological grounds, but also on the practical grounds that, based on experience in other sectors, it would be more difficult for unions to recruit, retain, and represent members in a privatized telco. Successive governments in the 1990s, formed first by the ALP and then by the conservative coalition, ${ }^{3}$ privatized other formerly state-owned enterprises such as the Commonwealth Bank and the national airline, QANTAS (Bamber et al 2009). Moves to privatize Telstra generated much more political controversy, however, resulting in a transition to full privatization (which was not finalized until 2006) much longer in duration than parallel developments in other Anglo-Saxon countries such as the United Kingdom and New Zealand.

Limited competition in the Australian telecommunications sector began in 1992 when the government granted licenses to two competitors to Telstra: Optus (fixed

${ }^{3} \mathrm{~A}$ coalition between the Liberal and National (formerly Country) parties. line and cell services) and Vodafone (only cell services). The result was a duopoly in domestic and international services, and a three-way oligopoly in cellular services (Brown 1996:3). Full deregulation remained a few years away, however.

The political climate changed with the election in 1996 of a conservative coalition government that aimed to sell Telstra and wanted it to operate on a more commercial basis. In 1997 the government fully deregulated the telecommunications sector, opening the market to all competitors, and partially privatized Telstra, selling one-third of its shares. The government sold a further $16.6 \%$ of Telstra shares in 1999 , leaving the government with a $50.1 \%$ majority ownership (ANAO 2000). In 2004 the coalition government was re-elected and, for the first time since taking office in 1996, won a majority of seats in the Senate-the upper house of the Australian parliament. Having control of both chambers allowed coalition leaders to complete the privatization of Telstra. In 2006 the government sold $35 \%$ of Telstra shares and transferred the remaining $17 \%$ to the Future Fund, ${ }^{4}$ which was at arm's length from the government. Thus, by 2006 government ownership of Telstra had ended, and the company was completely in the private sector.

Nevertheless, Telstra remained the dominant telco in Australia, to a greater extent than its counterparts in other countries, such as the United Kingdom. To an extent, this reflected Australia's relatively small population and large land area, which tended to make it uneconomical for competitors to roll out their own networks. The Australian Consumer and Competition Commission accepted an argument that Telstra is unique in that its "considerable geographic reach and significant cost to duplicate its network indicates that it exhibits natural monopoly characteristics for the provision of basic access

${ }^{4}$ The "Future Fund" was created by the conservative government as an autonomous "financial asset fund with the defined purpose of accumulating sufficient financial assets to offset the Australian Government's unfunded superannuation liability" (AGFF 2006). The Fund could subsequently sell its Telstra shares if it wished. 
and other fixed services" (ACCC 2006:14). Telstra's competitors, in contrast, are smaller, leaner operations that may "piggy-back" on Telstra's network. Telstra's "home country" advantage was further evidenced by its local versus international ventures. While it remained a highly profitable company in Australia, most of its sporadic forays into international markets incurred financial losses and associated write-downs (Kruger 2003).

\section{Labor Market Considerations}

While governments were deregulating telecommunications, they were also implementing fundamental changes to the regulation of the Australian labor market. In contrast to the United States and the United Kingdom, which have long had decentralized ER systems, Australian ER regulation for most of the twentieth century included a strong role for centralized industrial tribunals, wage-determination arrangements, and compulsory arbitration. This pluralist ER system provided a key role for unions, which inherited a tradition of adversarial ER. Once a union was registered with an industrial tribunal, it had, in effect, sole bargaining rights for all workers in its coverage (Lansbury and Wailes 2004). This system of regulation helped to sustain the unions' role and membership.

During the period 1983-96, when the Labor Party formed the government, there was an increase in union influence, based in part on a series of Accords ${ }^{5}$ between the government and the Australian Council of Trade Unions (ACTU). These agreements were aimed at shifting Australia toward a more consensus-based ER system, in an endeavor to emulate some of the institutions that characterize coordinated market economies (Hall and Soskice 2001; Bamber et al. 2004). By the early 1990s, the centralized system was facing increasing criticism. Representatives of the major actors-governments, employ-

${ }^{5}$ These Accords were agreements that were influenced by corporatist-style consensus models including examples from European coordinated market economies. In short, unions agreed to moderate wage demands in return for "social wages" and a greater say in domestic policy-making (Davis and Lansbury 1998:125-30). ers, and unions-were calling for greater flexibility to engage in enterprise-based bargaining (Gardner and Palmer 1997:33). Consequently, collective bargaining was increasingly decentralized to the enterprise level, while working conditions and rates of pay prescribed by awards ${ }^{6}$ were retained as a safety net for some categories of workers.

The 1996-2007 conservative coalition government was committed to changing such ER arrangements. It further decentralized the labor market by implementing the Workplace Relations Act (WRA) 1996. The general emphasis of the WRA was to reduce the roles of centralized tribunals and of unions by shifting ER further toward direct individualized relations between employers and their employees. The WRA included provisions to encourage individual employment contracts through so-called Australian Workplace Agreements (AWAs).

As noted above, following its re-election in 2004, the conservative government won a majority in both houses of Parliament. This allowed it to enact legislation without the support of the minor parties in the Senate. Following its commitment to further industrial relations reforms, it introduced tougher and more controversial legislation-the WorkChoices Act (2005). This was radical legislation against the background of Australia's pluralist ER traditions. It further downgraded the role of awards to that of only a minimum safety net covering only five conditions. The Act also specified areas that were excluded from bargaining and substantially reduced the powers of the AIRC; and it allowed employers to specify individual contracts (AWAs) as a condition of employment (Baird et al. 2006), so that the prospective employee had to choose between accepting the employer's individual contract or not getting the job. The Orwellian-sounding WorkChoices Act was branded "No Choices" by some critics.

In short, Australia shifted from a pluraliststyle ER system toward a unitarist ER framework that greatly constrained the role of

\footnotetext{
${ }^{6}$ An award in this context is a legally enforceable collective labor contract, determined by an industrial relations commission or arbitration tribunal.
} 
unions. The aim of this process was to foster change toward a U.S.-style individualized labor market. However, the conservative coalition lost the 2007 election, with widespread concern about the WorkChoices legislation seen as a major factor contributing to this election outcome. The incoming Labor government's ER platform included gradually discontinuing AWAs and again providing broader scope for awards. Nonetheless, Australia will not return to a centralized ER framework. The post-2007 Labor government has made only limited modifications to the WorkChoicesregime. This echoes the approach of the post-1997 new Labour government in the United Kingdom, which retained many of the ER policies that had been introduced by the government of Margaret Thatcher.

\section{Trade Unions}

Until the 1990s, at Telstra nearly all bluecollar and white-collar workers and a large proportion of managers were union members. In 1992 Telstra negotiated with 15 different unions (Bamber et al. 1997:135). This generated a level of bargaining fragmentation not generally seen in comparable telecos in other countries. This large number of unions reflected Australia's history of occupation-based union organization that, in some instances, allowed separate unions to cover narrow categories of employees. It also reflected Telstra's former policy of performing much of its generic work in-house. After Telstra outsourced this generic work, it no longer had to deal with the associated unions.

An Australian Council of Trade Unions (ACTU) strategy that encouraged union amalgamations during the 1980 s and early 1990s further helped Telstra to decrease the number of unions with which it bargained. The ACTU strategy was based on the premise that larger unions would have more resources and bargaining power, while the rationalization of their structures would lead to efficiencies, including less duplication of activities. As a result of the outsourcing of generic work and the ACTU amalgamation strategy, by 1993 the number of main unions that Telstra negotiated with had been reduced from fifteen to three: the Communication
Workers Union (CWU), the Community and Public Sector Union (CPSU), and the Australian Manufacturing Workers Union (AMWU). In 1994 the CWU merged with the Telecommunications Officers' Association and the Electrical, Electronics, Plumbing, and Allied Workers' Union to form the Communication, Electrical, and Plumbing Union (CEPU) (Rice 1996:34). The CEPU and CPSU then acted as a single bargaining agent for all unions in the telco (Telstra 1998a). While the CEPU has more members at Telstra than any other union, the CPSU has a wider membership base outside Telstra and is a larger union in total membership. The CEPU tended to cover field workers, such as technicians, linesmen, and operator services, while the CPSU generally covered white-collar workers. However, there were some overlaps in their coverage, which caused problems. Such problems were compounded because, despite the fact that various unions had officially amalgamated in the 1990s, some of the historical intra-union tensions continued. In many respects, the CEPU continued to operate as a collection of different sections/ divisions rather than as a unified cohesive whole (interviews at CEPU 2007). In 2009, rivalries and separate branch structures still divided the technicians' and linesmen's factions of the telecommunications section of the CEPU, even though they had supposedly amalgamated 17 years earlier. This fragmentation has reduced the effectiveness of the unions. It distracted and weakened them, not least because it precipitated demarcation and other tensions (interviews 2009).

\section{Industry Restructuring, Outsourcing, and Downsizing}

Following deregulation, Telstra changed its structure in an attempt to become a more market-driven, customer-focused company with an emphasis on increasing revenues and cutting costs: "We are transforming from a regulation-centric incumbent into a fully integrated, global media-communications company" (Telstra 2008:1). The restructured telco was a leaner core business supported by sub-contractors, subsidiaries, joint ventures, strategic alliances, and suppliers. Sako and 
Table 1. Milestones in the Australian Telecommunications Sector and at Telstra.*

\begin{tabular}{|c|c|}
\hline Year & Event \\
\hline $1983-96$ & $\begin{array}{l}\text { Under successive Labor governments, union influence in Australia increases. The government } \\
\text { and the Australian Council of Trade Unions sign Accords aimed at achieving a more consensus- } \\
\text { based ER system. }\end{array}$ \\
\hline 1989 & Telstra's forerunner, "Telecom Australia," is corporatized. \\
\hline 1990 & A+ Telecom Australia union density is more than $90 \%$. \\
\hline early 1990s & $\begin{array}{l}\text { Telecom Australia begins outsourcing unskilled generic work and introduces individual contracts } \\
\text { for some groups of staff. Unions fight back with work stoppages, work bans, and other actions. }\end{array}$ \\
\hline 1992 & $\begin{array}{l}\text { The government initiates limited de-regulation and competition: Optus (fixed line and cell ser- } \\
\text { vices) begins operations, and Vodaphone (cell services) is granted a license. }\end{array}$ \\
\hline 1992-93 & $\begin{array}{l}\text { Due to the outsourcing of generic work and a union amalgamation strategy, the number of main } \\
\text { unions with which Telecom Australia negotiates falls from } 15 \text { to } 3 \text {. }\end{array}$ \\
\hline \multirow[t]{2}{*}{1993} & $\begin{array}{l}\text { After the merger of Telecom Australia and the Overseas Telecommunications Corporation (OTC), } \\
\text { the new entity is renamed Telstra. }\end{array}$ \\
\hline & $\begin{array}{l}\text { Following the incumbent Labor government's unexpected electoral victory, Telstra and the unions } \\
\text { announce the "Participative Approach," which sees unions as partners. }\end{array}$ \\
\hline 1994 & $\begin{array}{l}\text { Three unions merge to form CEPU (the Communication, Electrical, and Plumbing Union). CEPU } \\
\text { and CPSU (the Community and Public Sector Union) act as a single bargaining agent for all } \\
\text { unions in Telstra. }\end{array}$ \\
\hline \multirow[t]{3}{*}{1995} & Telstra holds $50 \%$ equity in Foxtel, a firm providing pay-TV services. \\
\hline & Telstra hires human resources executives known for their anti-unionism. \\
\hline & $\begin{array}{l}\text { The Participative Approach is reaffirmed in Telstra's 1995-97 collective agreement, but is soon } \\
\text { abandoned. }\end{array}$ \\
\hline 1996 & Election of a conservative coalition government. \\
\hline late $1990 \mathrm{~s}$ & $\begin{array}{l}\text { Telstra outsources skilled technical work; accelerates its downsizing; delegates many ER duties to } \\
\text { line managers; allegedly seeks to lay off ER managers who are union members; pressures employ- } \\
\text { ees being paid more than } \$ 50,000 \text { to switch to individual employment contracts; and asserts that } \\
\text { many issues it formerly negotiated with unions would be matters of corporate "policy." The unions } \\
\text { fight some of these changes, but acquiesce to others. }\end{array}$ \\
\hline \multirow[t]{3}{*}{1997} & Telstra is partially privatized-one-third of its shares are sold. \\
\hline & The telecommunications sector is deregulated-open to full competition. \\
\hline & $10 \%$ of Telstra workers are covered by individual contracts (AWAs). \\
\hline
\end{tabular}

Continued.

Jackson (2006:349) link such restructuring to ER practices. In the past, Telstra workers had enjoyed terms and conditions of employment, including above-average wages, that reflected the company's former position as a monopoly. While the post-1996 conservative government's privatization plans were being frustrated in the Senate, Telstra moved parts of its business into subsidiaries, a strategy that also allowed it to shift workers out of collective bargaining coverage to less costly individualized terms and conditions of employment. The unions suspected that Telstra was trying to privatize itself by stealth (interviews, 1999-2002).
Telstra also entered into strategic partnerships with firms that complemented its existing services. For example, it made equity investments in collaboration with Internet-related firms, such as Microsoft, that could provide its customers with content and services via Telstra's Internet network. In 1995 Telstra also entered into a joint venture with television and news firms by taking $50 \%$ equity in Foxtel, a firm that provided pay-TV services via Telstra's fiber optic cable network (Telstra 1995:74). New products and services were then being generated by the skills of workers who were not employed by Telstra.

Telstra's cost-cutting strategies included 
Table 1. Continued.

\begin{tabular}{|c|c|}
\hline Year & Event \\
\hline 1998 & $\begin{array}{l}\text { The 1998-2000 collective agreement assigns separate terms and conditions to three work force seg- } \\
\text { ments. Unions reluctantly agree, in part because of substantial wage increases. }\end{array}$ \\
\hline 1999 & $\begin{array}{l}\text { The government sells a further } 16.6 \% \text { of Telstra's shares. It retains } 50.1 \% \text { majority ownership of } \\
\text { Telstra. }\end{array}$ \\
\hline 2000 & Telstra discontinues the automatic deduction of union dues. \\
\hline 2003 & Telstra has reduced its work force to 37,169, from 84,000 in 1989 . \\
\hline 2004 & $\begin{array}{l}\text { The coalition government, upon its re-election, for the first time since taking office in } 1996 \text { has a } \\
\text { majority of seats in the Senate. This paves the way for it to fully privatize Telstra. }\end{array}$ \\
\hline \multirow[t]{3}{*}{2005} & Telstra's new CEO, Sol Trujillo, reinforces Telstra's anti-union stance. \\
\hline & Telstra announces plans to cut another 12,000 jobs during the next five years. \\
\hline & $\begin{array}{l}\text { The conservative government's WorkChoices law downgrades the role of awards, excludes some } \\
\text { matters from bargaining, reduces the powers of the Industrial Relations Commission, and allows } \\
\text { employers to specify AWAs as a condition of employment. }\end{array}$ \\
\hline 2005-2006 & Telstra outsources the construction of its third-generation mobile telephone network. \\
\hline 2006 & $\begin{array}{l}\text { The government sells a further } 35 \% \text { of Telstra shares; the remaining } 17 \% \text { are transferred to the } \\
\text { government's "Future Fund," to be sold in due course. }\end{array}$ \\
\hline \multirow[t]{2}{*}{2007} & $\begin{array}{l}\text { A Labor government is elected, promising to discontinue AWAs. Before and after the election, } \\
\text { Telstra hastens to persuade as many workers as possible to sign AWAs. }\end{array}$ \\
\hline & $\begin{array}{l}\text { More than } 50 \% \text { of Telstra workers are covered by AWAs, compared to less than } 8 \% \text { of all Australian } \\
\text { workers. }\end{array}$ \\
\hline 2008 & $\begin{array}{l}\text { Telstra discontinues bargaining with the unions and announces that it intends to introduce a non- } \\
\text { union collective agreement in its Wholesale Business Unit. }\end{array}$ \\
\hline 2009 & $\begin{array}{l}\text { The government's Fair Work law promotes "good faith bargaining." Telstra appoints a new CEO, } \\
\text { David Thodey. It adopts a more conciliatory approach to the government and unions, announcing } \\
\text { that it will resume bargaining with unions. }\end{array}$ \\
\hline
\end{tabular}

Sources: Various, including Telstra annual reports; Brown (1996:3); Haynes (2006); media reports.

*Earlier, Telstra was known as the Australian and Overseas Telecommunications Corporation, Telecom Australia, and before that it was part of the Postmaster General's Department (PMG) a government department responsible for postal and telephone service and radio and TV broadcasting, among other things. To avoid confusion, this article generally uses the name Telstra.

much downsizing and outsourcing, supported by the introduction of new technologies and work practices. Telstra initially outsourced unskilled generic work in the first half of the 1990s. This reflected a strategic approach to outsourcing, as such work is $\underline{n o t}$ part of Telstra's core competencies and it can easily be purchased as services in external markets. But by the late 1990s, Telstra was outsourcing more skilled technical work. Arguably this reflected a less strategic approach to outsourcing, for such work is firm-specific and linked to the firm's intrinsic competitive advantage (Teece 1984; Williamson 1991). Further, interviews with Telstra managers suggest that the outsourcing of technical work was not always well implemented; many managers had little experience in managing external contractors. This led to cost overruns and to contractors being paid before they had completed their assigned projects. Telstra then offered training programs to try to improve the performance of their project managers. Therefore, at least in the initial stages, outsourcing such work does not seem to have yielded substantial gains, at least in cost/benefit terms. Rather, these strategies appear to have been at least partly motivated by management's desire to reduce "head-count" as well as to divide and rule the technical work force-which had been highly unionized. Telstra then introduced processes that compared the performance/ productivity of in-house workers with that of subcontractors. But union officials alleged that subcontractors were allocated "easier" 
jobs in an attempt to pressure in-house technicians to increase their productivity. Union officials described these practices as "work intensification."

Rapidly changing telecommunications technologies played a further role in Telstra's downsizing strategies, as many jobs became redundant. For example, new technologies, especially the digitization of the network, are what enabled Telstra to reduce the number of its staffed exchanges from about 5,000 in the earlier period of analog technology to about 200 by 2007 . If Telstra had rolled out a proposed new fiber-to-the-node (FTTN) network, it could have operated with as little as one exchange for the whole of Australia, though in reality it would probably have operated with around six to twelve exchanges in total (interview with former Telstra manager 2007). The government's decision in 2009 to change the FTTN strategy to a higherspeed fiber to the premises (FTTP) national broadband network (Conroy 2009) is likely to further hasten the reduction in the number of jobs that are related to work on the copper wire network.

Partly as a result of such changes, in the late 1990s Telstra accelerated its "downsizing," as management sought to reduce costs in the then partially privatized company. By 2003, Telstra had reduced its work force to only 37,169 employees-a massive decrease from the 84,000 workers that it had employed in 1989 (see Figure 1). Employee numbers appeared to stabilize for the next two years, but in 2005, Telstra announced plans to cut another 12,000 jobs over the next five years (Colley 2007).

Despite the general downsizing trend, over one short period-from 1993 to 1995-Telstra increased its permanent work force from 69,000 to more than 73,000 employees. This increase was associated with Telstra rushing to install a pay-TV cable network to compete with the new entrant telco, Optus. But in view of Telstra's subsequent outsourcing strategies, such increases in worker numbers are unlikely to be repeated. In 2005-2006 Telstra outsourced the construction of its third-generation mobile telephone network to the multinational enterprise Siemens. This was essentially a turn-key arrangement, with specialist workers being imported from overseas on short-term contracts. In the interviews, Telstra managers commented that future large-scale capital investments are also likely to be one-off contracts with external providers.

Despite the increased number of telecommunications providers since deregulation, downsizing at Telstra has not been offset by large increases in total employment in the Australian telecommunications sector. In 2002-2003 total employment in the whole sector was around 67,750 (Eason 2006). To put this in perspective, Figure 1 shows that in 1995 Telstra alone employed more than 73,000 people. In 2005 , most telecommunications workers were still employed by the five biggest Australian telcos, and more than half of them were employed by Telstra. Most of Telstra's competitors are smaller operators that generally use either the Telstra or Optus network and employ mainly non-union labor with lower labor costs. This is a factor that adds pressure on Telstra to reduce its operating costs.

\section{Management ER Strategies and Union Responses}

In the late 1980s Telstra's work force and ER strategies reflected its public-sector monopoly context. This included a large and stable work force, low levels of employee turnover, and high unionization rates. In 1990 the average period of service for Telstra workers was almost 13 years, ${ }^{7}$ and there was a union density of more than $90 \%$ (Telecom 1990:153, 171; interviews at CEPU, 1998). Telstra managers generally seemed to take it for granted that unions were legitimate representatives of Telstra workers, and many workers' issues were settled through the unions. At that time, Telstra and union officials said, many employees seemed to be committed to their union as well as to their manager. For example, employees with problems often preferred to consult their local union, rather than their manager. Union officials would

\footnotetext{
${ }^{7}$ The average period of service for Telstra technicians, in particular, was approximately 18 years.
} 
Figure 1. Telstra's Full-Time Work Force, 1989-2005.

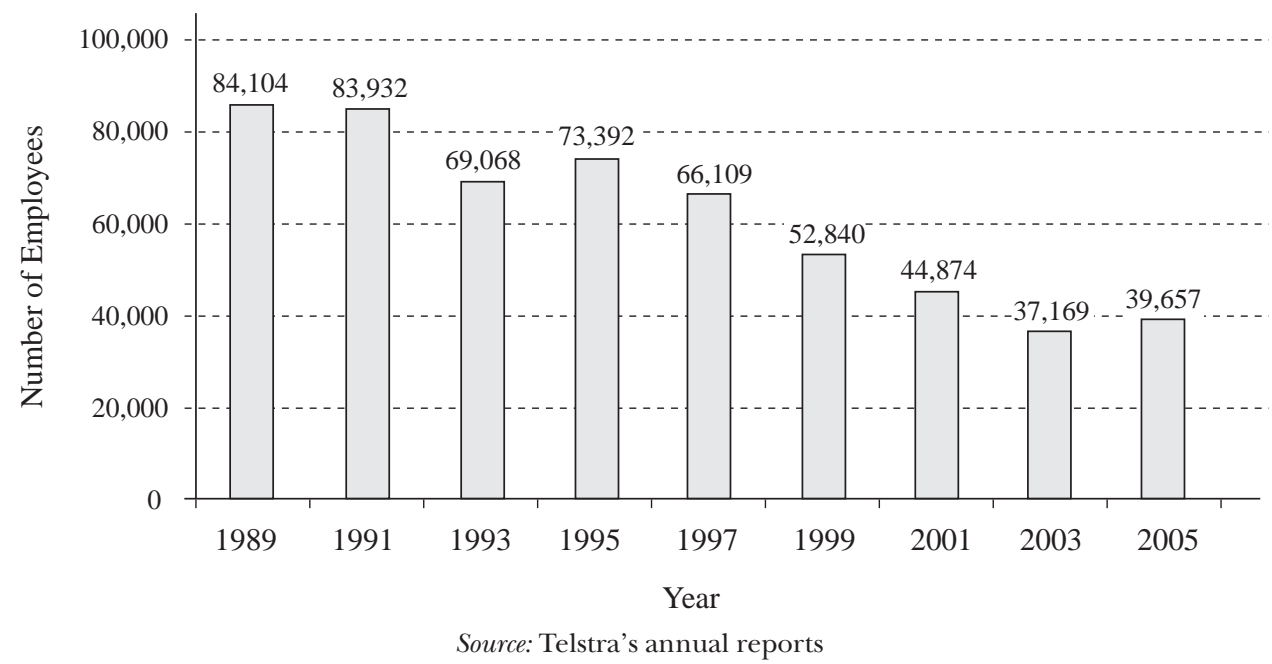

then discuss the problem with the manager on the worker's behalf (interviews at Telstra, 2000-2002). Many Telstra managers were also union members, and some had been voluntary union officials earlier in their careers. But the relationship between management and the unions began to deteriorate after corporatization in 1989, when Telstra, facing impending deregulation, attempted to become more competitive partly by striving for greater functional and numerical flexibility among its workers. As outlined above, this included much downsizing.

In the early 1990s Telstra introduced individual contracts for many of its senior managers and for other groups of staff (Bamber et al. 1997:137-38). These strategies did not reflect government policy, for the then Labor government was friendly toward unions. Unions, drawing on their reserves of political and industrial power, fought such strategies using their influence with the Labor government as well as with work stoppages, the imposition of work bans, and other actions (Gray 1992; Barton and Teicher 1999:15-16). By 1994 some Telstra senior executives had become increasingly concerned about the rise in industrial disputes and the company's deteriorating relationship with the unions.

Union officials suggested that Telstra's ER initiatives in the early 1990s were linked to an assumption by senior executives that the conservative opposition parties were likely to defeat the incumbent Labor government at the next general election. The coalition parties proposed to privatize Telstra and to change labor law. However, the incumbent Labor government enjoyed a surprise victory in the 1993 election. Unexpectedly, Telstra management had to continue to deal with a union-friendly Labor government owner for the next three years, with no immediate prospect of privatization.

One of Telstra's responses was to initiate discussions with the unions that led to the adoption of the "Participative Approach." This aimed to treat unions as independent and approximately equal parties that would be involved "in the early stages of strategic and other levels of planning and change processes" (Telstra 1994, in Shadur et al. 2003:311). This approach included the creation of "consultative committees" across the various organizational units of the company (Rice 1998:542). The Participative Approach might be seen as a weak form of co-determination at the company level. It was an idiosyncratic ER innovation given that Australia did not have much history of such approaches. Further, no other large Australian firms had engaged in similar participative approaches. What then was the motivation 
behind Telstra management's adoption of this approach? First, Telstra's then senior ER executive, Ian McPhee, was a long-time advocate of employee participation in management decision-making, and he proposed its adoption. Second, this could be considered a pragmatic managerial approach inasmuch as the unions were still relatively strong during the early 1990s (Rice 1996). Further, Telstra's Labor party "union-friendly" government owner had been unexpectedly re-elected. Arguably, the Participative Approach could be seen as a company-level adaptation of the above-mentioned accords between the Labor government and the unions.

While the Participative Approach was supposed to herald a new era of cooperation, management and the unions differed in their interpretation of the approach and their view of Telstra's future directions (Rice 1996; Ross 2003). Although some union officials had hoped that the Participative Approach could develop into something approximating the European notion of co-determination, this was not to be. When proposing the Participative Approach, Telstra did not link it to board-level representation or European-style works councils, two features integral to codetermination. In practice it was seen rather more as a way of trying to foster a form of mutual-gains-style negotiations. However, it was not implemented consistently, and many of the key players seemed to be cynical or generally lacking in enthusiasm about it. Union officials alleged that many Telstra managers paid only lip service to the approach and made too few genuine attempts to incorporate the prescribed approach in their sections. Telstra managers countered that the Participative Approach wasted too much of their time and that the unions had agreed to the Participative Approach only to gain substantial pay increases, with no commitment to delivering the envisaged gains in labor productivity.

A major underlying problem was Australian managers' and unions' inexperience in implementing such an approach, a deficit arising from decades during which unions negotiated with employers at a centralized level, without much workplace involvement. Telstra and the unions, then, lacked the skills, organization, and trust required to implement the Participative Approach successfully. The unions did not train officials to work within this new approach. Implementation was further hindered by Telstra's continued downsizing. Union officials indicated that it was difficult for them to play a positive role at consultative meetings while their members were being laid off. One Telstra manager said that "many of the consultative committees resorted to more traditional forms of industrial relations and beat one another up!" (Interviews at Telstra 2002.) It was not surprising, then, that soon there were signs of strain associated with implementing the Participative Approach.

Nevertheless, the Participative Approach was reaffirmed in Telstra's 1995-97 collective agreement. This agreement included substantial pay increases in return for guarantees that the unions "would not involve themselves in major strike activity for the duration of the agreements and would actively participate in a program of cost reduction and service quality improvement" (Rice 1996:97). Again critics suggested that this resembled an expedient "exchange deal" between management and the unions rather than a genuine attempt at cooperation (for example, Ku 2006:146). Perhaps this is why the parties did not continue with the Participative Approach for much longer.

In 1995 Telstra had signaled a change in ER policy by hiring a new director of human resources, Rob Cartwright, and several associates, who in their former jobs had strongly challenged the role of unions at Rio Tinto/ Comalco (RTZ-CRA) (McDonald and Timo 1996; interviews at CEPU 2002). At Telstra they became known as the "Comalco Mafia" (interviews at Telstra 2002). These senior ER managers were ideologically opposed to unions and introduced a more unitarist ER approach that aimed to deal directly with employees. Their appointment reflected Telstra's dissatisfaction with the Participative

${ }^{8}$ Comalco is an Australian-based subsidiary of the Anglo-Australian multi-national enterprise Rio Tinto, which has a reputation for taking a tough stance toward unions. 
Approach, which managers were soon told to abandon (Interviews at Telstra 2002). From our interviews with union officials, we infer that many of them, too, were unhappy with the Participative Approach-it consumed considerable time and stretched union resources-and some of them acquiesced in its demise.

The election of the conservative government in 1996 was a further turning point in Telstra's policy toward the unions. The conservative government adopted a much tougher approach to industrial relations, so the unions lost much of their influence in the polity and economy.

By the late 1990s Telstra's senior ER executives held the view that, in the past, Telstra managers had been too sympathetic to the unions, which was not conducive to implementing organizational change. Telstra's new ER tactics included several measures to reverse that legacy. First, many ER duties were delegated to line managers, which allowed Telstra to reduce the size of its central ER staff. Some interviewees alleged that, second, Telstra sought to lay off ER managers who were union members. Third, employees being paid more than $\$ 50,000^{9}$ per year were pressured to switch to individual employment contracts. Telstra also released new organizational principles specifying that ER issues were not to be settled by "third parties" such as unions (Barton and Teicher 1999:26). These tactics had serious repercussions for the unions.

\section{Collective Bargaining versus Individual Agreements}

The bargaining process for the 1998-2000 collective agreement was protracted and involved industrial disputes at Telstra; there was a hardening of Telstra's executives' policies toward the unions. Telstra made separate agreements with three work force segments: (1) the Customer Field Work Force, (2) Network Design and Construction, and (3) the other Telstra workers.

\footnotetext{
${ }^{9}$ Sums of money cited in this article are in Australian dollars; at the time of writing, one Australian dollar was equal to 79 U.S. cents.
}

While they were not in favor of having three separate agreements, the unions eventually assented to them, in part because substantial wage increases were included (Telstra 1998b). These new enterprise bargaining agreements (EBAs) delivered to Telstra some of the ER changes it had been seeking, including provisions that allowed field workers to cross various demarcation lines that had traditionally separated occupations (interviews at Telstra 2002).

Telstra then introduced individual employment contracts (AWAs) to increase work force flexibility and reduce union influence. Managers used AWAs as much as possible to try to individualize the employment relationship between Telstra and its workers. Unions could get involved in negotiating AWAs only if employees authorized them to act as their bargaining agent. Between 1997 and 2007 Telstra increased the proportion of workers covered by individual AWAs from $10 \%$ to more than $50 \%$ of the work force (interviews at Telstra and CEPU 1997-2007). This rate was well above the national average; by 2007 the proportion of all Australian workers on individual AWAs was less than 8\% (van Wanrooy et al. 2007:35). Telstra managers said that part of the rationale was to shift workers' allegiance away from the union toward Telstra. For example, because many middle managers had formerly been union members, Telstra tried to move such managers on to AWAs as a strategy to bring middle managers closer to Telstra and to distance them further from the unions (interviews at Telstra 2002).

After signing individual contracts, many workers subsequently left the union. The introduction of AWAs, therefore, limited industrial action by dividing the work force between non-union workers on individual contracts and unionized workers covered by a collective agreement. When the unions initiated strikes in the late 1990s, Telstra managers were able to keep many areas operating by using non-union workers who were on AWAs.

During this period Telstra abandoned most of its joint boards, which used to include union representation (these boards were legacies of the period when Telstra had been a public-sector enterprise), and reduced the scope of its enterprise bargaining. In 
accord with the legal framework proposed by the government, Telstra argued that future enterprise agreements should include no conditions beyond the 20 "allowable matters" envisaged by the proposed labor laws. Instead, Telstra said that some such conditions would merely become corporate "policy" (interviews at Telstra 2000). This was a major change. In contrast to the provisions of an award or collective agreement, such "policy" could be unilaterally altered by managers without the consent of the workers or their unions. Telstra's shift toward such a unitarist approach was further demonstrated in 2000 when it removed the automatic payroll deduction of union dues from workers' salaries-five years before the government outlawed such arrangements more generally.

In 2005 Telstra appointed as CEO Sol Trujillo, an American who had formerly been CEO of US West, a "Baby Bell" telco. Trujillo recruited several executives from the United States to be involved in his new leadership team that the media quickly dubbed the "amigos." This group of senior executives reinforced Telstra's anti-union stance.

Union responses to the changes in management attitudes were pragmatic. The unions were willing to initiate disputes to support claims on behalf of their members. But when faced with the large costs involved in protracted industrial campaigns and potentially high litigation costs, they generally compromised pragmatically with Telstra, including agreements that introduced more flexible working conditions and abolished some job demarcations. Despite these trade-offs, Telstra workers still enjoyed employment conditions that were above the market average, and the unions were able to negotiate significant wage increases for their members-between 1995 and 2002, wage increases totaled 27\%. But Telstra's downsizing and AWA strategies led to a sharp decline in union membership numbers and union income. Interviews suggest that by 2007 union coverage of Telstra employees had dropped to around half of the work force (interviews at Telstra and CEPU; Internal CEPU reports). Tung (2009) estimates that by mid-2009 union membership had fallen further to only about $20 \%$ of the work force, but such figures are difficult to verify. Union density at Telstra might be more like $30 \%$ if all the subcontractors and those on individual contracts were excluded from the calculation. Unions were relatively successful at retaining existing members, but much less successful at recruiting new ones. Further, the unions have had little success in recruiting members in Telstra's new competitors. Extrapolation of the downward trend of union membership in the telecommunications section of the CEPU between 2002 and 2007 implies that by 2011 some of this section's union branches will no longer be viable.

In 2007, opinion polls predicted that the Labor party would defeat the conservative government in the forthcoming election. Given that the Labor party had promised to abolish individual employment contracts, Telstra urgently tried to "persuade" as many workers as possible to sign on to AWAs before the election. Telstra could then "lock" these workers into individual agreements for up to another five years. Following the 2007 election of the Labor government, Telstra maintained its anti-union stance and continued to move even more workers to AWAs before the new government acted to phase-out AWAs.

Unions claim that an additional 15,000 Telstra employees were moved to AWAs during this post-election period (CEPU 2008a). Telstra then stopped bargaining with the unions in mid-2008, before announcing that it intended to introduce a non-union collective agreement in its Wholesale Business Unit (CEPU 2008b). Media reports claimed that Telstra's "union busting" strategies included initiating more non-union agreements across other divisions in an attempt to cut Telstra's labor costs by $\$ 50$ million by limiting wage increases (Davis 2008; Hannan 2008a,b). Despite the 2007 election of a Labor government, in 2008 Telstra discontinued bargaining with unions. This prompted unions to initiate forms of industrial-relations "guerrilla warfare" against Telstra.

An alternative response to this change of government might have been immediately to re-engage with the unions in an attempt to rekindle more of a partnership approach against the background of a more "unionfriendly" institutional context. Telstra's 
leaders' ideology appeared to have prevented such a response. Telstra's CEO, Sol Trujillo, continued to see unions as enemies to be marginalized. In May 2009, however, months before the end of his contract, Trujillo returned to the United States. According to the unions, he left with a "golden parachute" estimated at more than $\$ 20$ million. This was in spite of Telstra's share price having slumped from more than $\$ 5$ when Mr Trujillo became CEO in 2005 to less than $\$ 3.70$ - a decline of more than 25\%. Before departing, he announced a better-than-expected halfyear profit of $\$ 1.92$ billion, but also claimed to have eliminated 10,000 jobs at Telstra. Under his leadership, the state of Telstra's relations with the government and with unions fell to a new low level.

The post-2007 Labor government enacted policies that promised to promote, among other things, the notion of "good faith bargaining" between employers and unions. Against this background, the new CEO, David Thodey, changed tactics and soon adopted a much more conciliatory approach to the government and unions. For example, in June 2009, Telstra resumed bargaining with the unions and the CEPU suspended its "guerrilla-style" industrial-relations campaign. However, the new government policy had been more influential than the unions' campaign in inducing Telstra to return to bargaining. On July 1, 2009, Telstra and its main unions published an agreement to "progress their working relationship." This included such clauses as "Telstra is committed to bargaining in good faith under the new laws with unions representing Telstra employees" (Telstra 2009; Tung 2009). This seemed to signal a change from Telstra's previous policy.

\section{Conclusions}

Katz (1997) observed that Australia's former ER regulatory framework limited attempts by Telstra's competitors to set up non-union agreements, which substantially differed from the collective unionbased agreements then in force at Telstra (1997:250). But even while Katz was writing his book, a new conservative government was changing the regulatory framework. This gave Telstra, as well as its competitors, scope to set up non-union arrangements, including non-union individual contracts. Against the background of this changing institutional context, we return to our research question: to what extent were Telstra's ER-policy-related strategic choices made autonomously, rather than merely reflecting the policies of successive governments?

Our research shows that successive Australian governments inevitably continued to influence Telstra's strategies, even after deregulation. This influence mirrored the ideological perspective of the political party in power, the government's regulatory role in telecommunications and the labor market, and the government's status as Telstra's majority shareholder until 2006. In this regard, the changes to labor laws were crucial in enabling Telstra management to implement unitarist ER strategies.

However, in contrast to Telecom New Zealand, the counterpart telco across the Tasman Sea, Telstra did not adopt anti-union strategies immediately following deregulation. This illustrated Telstra's scope for strategic choice. Instead, Telstra tried a Participative Approach with the unions in the early 1990s. While this was an autonomous decision of Telstra, it was also in tune with the preferences of the prevailing "union-friendly" Labor government. But this was not a simple case of institutional determinism. Rather, Telstra adopted an idiosyncratic ER policy within the broader context of Australian ER practices. The latter reflected an adversarial "us-against-them" legacy for much of the twentieth century, with no general moves toward industrial democracy or codetermination at company level. The Participative Approach was therefore a relatively autonomous strategic choice on the part of management and the unions that ran counter to the prevailing norms of this period. But even before the change of government in 1996, there were signs of quasi-autonomous change in Telstra's ER policy moving it away from its long practice of generally accommodating unions and collective bargaining.

Why did Telstra abandon such practices and decide to be more antagonistic to unions? To some extent, it was following examples set 
by U.S. and U.K. restructuring. Telstra hired key senior executives from the United States (including two CEOs) ${ }^{10}$ and sought advice from U.S.-oriented consulting companies. The policies of those key executives were implemented by new HR executives who had a history of anti-union activities in other industries. The ER legislative changes that followed the 1996 change of government gave Telstra much more scope to oppose unions, for the conservative government removed many of the former labor-market regulatory constraints to unitarist styles of management. Telstra executives formed the view that the alternative, more participatory process of restructuring that the company had tried was not viable, especially in the context of work force downsizing. Influential Telstra policymakers argued that unions were too militant and were hampering Telstra's efforts to change and compete with new-entrant telcos.

Against the background of these changing institutional constraints, ideology played a key role in Telstra's adoption of unitariststyle ER strategies that were antagonistic to the unions. While post-1996 ER legislation facilitated Telstra implementing new strategies, it did not force Telstra to do so. The post-1996 conservative government periodically complained that too few Australian employers were using the ER "weapons" it had provided for employers to "take on" the unions. But such complaints did not apply to Telstra, as it was a leader in this regard and tended to push the new ER legislation to the limit. ${ }^{11}$ This was evidenced by its approach to AWAs; the percentage of Telstra workers with these individual agreements greatly exceeded the national average. Most workers who wished to be employed at Telstra had little practical choice; they had to accept a

\footnotetext{
${ }^{10}$ Of Telstra's four CEOs since deregulation, Telstra hired two CEOs from the United States; the other two were Australians, but they had both been CEOs of an Australian subsidiary of a U.S. multi-national enterprise.

${ }^{11}$ The conservative government's then Minister for Industrial Relations was Peter Reith. In 1997 an article described Telstra's director of human resources, Rob Cartwright, as "one of 'Reith's Rambos'- the men who would push the envelope of the Workplace Relations Act in pursuit of total deregulation" (Bachelard 2001).
}

job on an individual-contract basis. Moreover, most workers who were placed on individual contracts left the union.

Telstra's approach to outsourcing also shows evidence of its changing ideological approach to ER. While its earlier outsourcing of generic work accords with a strategic approach to downsizing, its later outsourcing of skilled technical work contradicts organizational theories that suggest such core work should be retained within the firm (Carroll and Teece 1999; Teece 1982; Williamson 1996). Telstra managers admitted that the outsourcing of technical work was not always done well. Outsourcing in this context seemed to reflect a management bias against this unionized technical group of Telstra workers.

Telstra's continuing "tough" unitarist policies for another year and a half following the election of a Labor government in 2007 provide further evidence that its managers were making quasi-autonomous strategic choices. Despite the changing institutional context, Telstra managers maintained pressure on workers to shift to AWAs. When this was no longer legally possible, they then attempted to shift workers to other forms of non-union employment contracts. Telstra did not initially follow the spirit of the Labor government's ER policy, which provided more support for unions and collective bargaining; rather, it continued to aim to determine workers' terms and conditions from a unitarist perspective, by managerial prerogative.

Changing management ideology, then, played a major role in the content and timing of Telstra's strategic choices following deregulation of the sector. In particular, our study shows that Telstra adopted tough policies to implement a unitarist approach to ER. These strategies appeared to be driven by ideologically motivated senior executives.

We infer from contingency theories that firms, including telcos, adapt and develop strategies that best suit their changing institutional environments (Katz et al. 2003:574). But there tends to be a time lag. For example, it took around 18 months following the 2007 change of government before Telstra changed its ER tactics. This apparent change reflected the appointment of a new CEO in 
May 2009, combined with the increased institutional support available to unions from the post-2007 Labor government. The new CEO appeared to adopt a pragmatic view that it was not in Telstra's interests to continue with the anti-union and anti-government strategies of his predecessor. Although the government is no longer the owner, it remains the regulator of the product markets and the labor markets.

To what extent, then, will Telstra switch back from a unitarist to a pluralist approach? To what degree do these changes reflect the post-2007 Labor government's policies, including its Fair Work laws? It was significant that Telstra's 2009 agreement with the unions was announced on the same day that the Labor government's new Fair Work laws took effect. Initial indications are that this might herald a change of strategy from that of the Trujillo regime, which was formulated under the former conservative government. Nonetheless, it is too early to judge the extent to which this is a pragmatic change of tactics in a new institutional context or a fundamental attempt to re-engage with the unions. In either case it does not seem likely that Telstra will return to a genuine pluralist approach. It is still aiming to maintain an individualized employment relationship with its work force, with substantial components of their pay being related to individual performance. Although the new laws prescribe "good faith bargaining," it is too soon to evaluate the outcomes of such bargaining.

What then does the future hold for the Australian telco unions? One indication of the future for Telstra workers is the experience of workers at Telecom New Zealand (TNZ), a company that engaged in similar tactics in the 1990s under a conservative government (Ross 2002). TNZ succeeded in its goal of marginalizing unionism. The main union at TNZ did not adjust to the changed context and was put into liquidation. By the time the Labour party was re-elected in New Zealand in 1999 , only a few workers were still union members in TNZ; unions have not re-established a significant presence in that telco, nor is it likely that they will do so in the foreseeable future.

Unlike the 1983-1996 Labor government, the post-2007 Labor government does not see unions as a partner in government, despite their historical links. Although it has repealed the most reviled aspects of WorkChoices, the post-2007 Labor government will not rebuild all the institutional support that unions previously enjoyed. Therefore, their future growth and role depend on their ability to implement innovative recruitment and retention strategies, as well as to deliver successful bargaining outcomes. In view of the current relative weakness of unions and the legacy of hostility from Telstra and the other telcos, it will be a challenge for unions to reconstruct a major role in Australian telecommunications. 


\section{REFERENCES}

ACCC (Australian Consumer \& Competition Commission). 2006. "Telecommunications Market Indicator 2004-05." Canberra.

AGFF (Australian Government Future Fund). 2006. "Frequently Asked Questions." http://www.futurefund.gov.au/faqs (accessed December 18, 2006).

ANAO (Australian National Audit Office). 1998. "Sale of One-Third of Telstra." The Auditor-General, Audit Report No. 10 (1998-99). Canberra, ACT.

2000. "Second Tranche Sale of Telstra Shares." The Auditor-General, Audit Report No. 20 (2000-2001). Canberra, ACT.

Bachelard, Michael. 2001. "Former Rio Tinto Man One of Reith's Rambos." The Australian, July 4.

Baird, Marian, Bradon Ellem, and Alison Page. 2006. Human Resource Management: Strategies and Processes. Workchoices Update. Melbourne: Thomson.

Bamber, Greg J., Jody Hoffer Gittell, Thomas A. Kochan, and Andrew Von Nordenflycht. 2009. Up in the Air: How Airlines Can Improve Performance by Engaging Their Employees. Ithaca, N.Y.: Cornell University Press.

Bamber, Greg J., Russell D. Lansbury, and Nick Wailes, eds. 2004. International and Comparative Employment Relations: Globalisation and the Developed Market Economies, 4th ed. Thousand Oaks: Sage.

Bamber, GregJ., Mark Shadur, and David Simmons. 1997. "Australia." In Harry C. Katz, ed., Telecommunications: Restructuring Work and Employment Relations Worldwide, pp. 122-52. Ithaca, N.Y.: ILR Press (an imprint of Cornell University Press).

Barton, Ruth, and Julian Teicher. 1999. "The Consequences of Deregulation and Privatisation for Industrial Relations in Telstra." National Key Centre in Industrial Relations, Working Paper No. 65, Monash University, Melbourne.

Brown, Allan. 1996. "Reform and Regulation of Australian Telecommunications." Working Paper No. 5 (January), School of Economics, Faculty of Commerce and Administration, Griffith University, Nathan, Australia. Carroll, Glenn R., and David J. Teece, eds. 1999. Firms, Markets, and Hierarchies: The Transaction Cost Perspective. New York: Oxford University Press.

CEPU (Communication, Electrical, and Plumbing Union). 2008a. "EBA Special Edition." The Latest Telecommunications: The Journal of the Communication Workers Union (a division of the CEPU), No. 22. www. cepuqld.asn.au (accessed July 18, 2008).

2008b. The Latest Telecommunications: The Journal of the Communication Workers Union (a division of the CEPU), No. 28. www.cepuqld.asn.au (accessed Aug. 8, 2008).

Child, John. 1997. "Strategic Choice in the Analysis of Action, Structure, Organisations and Environment: Retrospect and Prospect." Organization Studies, Vol. 18, No. 1, pp. 43-76.

Colley, Andrew. 2007. "Telstra Axe Swings Again.” The Australian, June 14.

Conroy, Stephen. 2009. "New National Broadband Network." Media Release (April 7, 2009), Department for Broadband, Communications and the Digital
Economy, http://www.minister.dbcde.gov.au/media/ media_releases/2009/022.

Davis, Ed, and Russell Lansbury. 1998. "Employment Relations in Australia." In Russell Lansbury and Greg J. Bamber, eds., International and Comparative Employment Relations, pp. 110-52. Thousand Oaks: Sage.

Davis, Mark. 2008. "Revealed: Telstra's Secret Plan to Bust Unions." Sydney Morning Herald, Aug. 14.

Dean, James W., and Mark P. Sharfman. 1996. "Does Decision Process Matter? A Study of Strategic DecisionMaking Effectiveness." Academy of Management Journal, Vol. 39, No. 2, pp. 368-96.

DiMaggio, Paul J., and Walter W. Powell. 1983. "The Iron Cage Revisited: Institutional Isomorphism and Collective Rationality in Organizational Fields." American Sociological Review, Vol. 48, No. 2, pp. 147-60.

Eason, Ros. 2006. "Building for Growth in Telecommunications: A Communications Division Discussion Paper." Communication, Electrical and Plumbing Union (CEPU) Internal Discussion Paper, April.

Fox, Alan. 1974. Beyond Contract: Work, Power and Trust Relations. London: Faber.

Frumkin, Peter, and Joseph Galaskiewicz. 2004. "Institutional Isomorphism and Public Sector Organizations." Journal of Public Administration Research and Theory, Vol. 14, No. 3, pp. 283-307.

Gardner, Margaret, and Gill Palmer. 1997. Employment Relations: Industrial Relations and Human Resource Management in Australia, 2nd ed. Melbourne: Macmillan.

Geare, Alan, Fiona Edgar, and Ian Mcandrew. 2006. "Employment Relationships: Ideology and HRM Practice." International Journal of Human Resource Management, Vol. 17, No. 7, pp. 1190-1208.

Gibbs, Graham R. 2002. Qualitative Data Analysis: Explorations with NVivo. Philadelphia: Open University Press.

Gillham, Bill. 2000. Case Study Research Methods. London and New York: Continuum.

Gray, J. 1992. "Telecom Unions Resisting Bid to Sell Manufacturing Unit." Australian Financial Review, Mar. 17, p. 4.

Hall, Peter A., and David Soskice, eds. 2001. Varieties of Capitalism: The Institutional Foundations of Comparative Advantage. New York: Oxford University Press.

Hannan, Ewin. 2008a. "Telstra Faces New Claim of Pay Cuts." The Australian, Aug. 25.

2008b. "Telstra Fails in Union Bypass Bid." The Australian, Sept. 17.

Hannan, Michael T., and John H. Freeman. 1989. Organizational Ecology. Cambridge, Mass.: Harvard University Press.

Hyman, Richard. 1987. "Strategy or Structure? Capital, Labour and Control." Work, Employment E' Society, Vol. 1, No. 1, pp. 25-55.

Katz, Harry C., ed. 1997. Telecommunications: Restructuring Work and Employment Relations World-Wide. Ithaca, N.Y.: ILR Press (an imprint of Cornell University Press).

Katz, Harry, Rosemary Batt, and Jeffrey Keefe. 2003. "The Revitalization of the CWA: Integrating Collective Bargaining, Political Action, and Organizing." Industrial and Labor Relations Review, Vol. 56, No. 4, 
pp. 573-89.

Kruger, Colin. 2003. "Losses at Reach Still Hounding Telstra." Sydney Morning Herald, Dec. 12, http:/ / www. smh.com.au/articles/2003/12/08/1070732143671. html?from=storyrhs.

$\mathrm{Ku}$, Chen-Yen. 2006. "Union Effectiveness during Privatisation: Lessons from the Telecommunications Industry in Australia and Taiwan.” Ph.D. Thesis, School of Social Sciences, University of Adelaide.

Lansbury, Russell D., and Nick Wailes. 2004. "Employment Relations in Australia." In Greg J. Bamber, Russell D. Lansbury, and Nick Wailes, eds., International and Comparative Employment Relations: Globalisation and the Developed Market Economies, pp. 119-45. Thousand Oaks: Sage.

McDonald, Jim, and Nils Timo. 1996. "Killing the Union? Individualised Contracts and CRA." In Gerard Griffin, ed., Contemporary Research on Unions: Theory, Membership Organisation and Non-Standard Employment. National Key Centre in Industrial Relations, Monash University, Melbourne.

Rice, John Lewis. 1996. "Changing Employment Relations at Telstra Corporation: The Impact of Environment and Technology." Masters thesis, Queensland University of Technology, Brisbane.

1998. "The Transformation of Industrial Relations at Telstra Corporation: The More Things Change, the More They Stay the Same." In Raymond Harbridge, Claire Gadd, and Aaron Crawford, eds., Current Research in Industrial Relations: Proceedings of the 12th Association of Industrial Relations Academics of Australia and New Zealand (AIRAANZ) Conference. AIRAANZ (Wellington, New Zealand, Feb.), pp. 535-45.

Ross, Peter K. 2002. "Toward 'Relationship Management': Organisational and Work Force Restructuring at the Telecom Corporation of New Zealand (TCNZ)." New Zealand Journal of Industrial Relations, Vol. 27, No. 1, pp. 93-105.

2003. "Organisational and Workforce Restructuring in a Deregulated Environment: A Comparative Study of the Telecom Corporation of New Zealand (TCNZ) and Telstra." Ph.D. thesis, Griffith University, Australia.

2006. "Management Strategies in Transitional Economies: Organisational Restructuring and Employment Relations at Ceský Telecom." Employee Relations, Vol. 28, No. 2, pp. 184-200.

2008. "Management Strategies in the Czech Telecommunications Sector: A Comparative Study of Ceský Telecom and T-Mobile." International Journal of Human Resource Management, Vol. 19, No. 12, pp. 2217-34.

Sako, Mari, and Gregory Jackson. 2006. "Strategy Meets Institutions: The Transformation of ManagementLabor Relations at Deutsche Telekom and NTT." Industrial and Labor Relations Review, Vol. 59, No. 3, pp. 347-65.

Shadur, Mark A., K. Caught, and René Kienzle. 2003. "Organisational Change in Australasian Telecommunications Companies.” In Gary Madden, ed., Emerging Telecommunications Markets: The International Handbook of Telecommunications Economics, pp. 300-318. Cheltenham: Edward Elgar.

Teece, David J. 1982. "Toward an Economic Theory of the Multi-Product Firm." Journal of Economic Behavior and Organization, Vol. 3, No. 1, pp. 43-57.

1984. "Economic Analysis and Strategic Management." In Johannes M. Pennings, ed., Strategy for Decision Making in Complex Organizations, pp. 78-101. San Francisco: Jossey-Bass.

Telecom. 1990. "1989/1990 Annual Report to the Minister for Transport and Communications on the Progress of Affirmative Action Program for Equal Opportunity in Telecom Australia." Telecom Australia, Melbourne.

Telstra. 1995. Telstra Annual Report 1995. Melbourne: Telstra Corporation Ltd. .1998a. "Telstra Corporation 1995-97 Enterprise

Agreement." Melbourne: Telstra Corporation Ltd. 1998b. "Telstra Secures Union Support for Work-

place Change.” Press Release, Oct. 22. Melbourne: Telstra Corporation Ltd. 2001. Telstra Annual Report. Melbourne: Telstra Corporation Ltd. 2008. "Telstra Transformation: Redefining the Business. Full-Year Shareholder Update.” Melbourne: Telstra Corporation Ltd. 2009. "Principles Relating to a Productive Working Relationship." Melbourne: Telstra Corporation Ltd, with Australian Council of Trade Unions (ACTU), Communications, Electrical and Plumbing Union (CEPU), Community and Public Sector Union (CPSU), and Association of Professional Engineers, Scientists \& Managers Australia (APESMA).

Tung, Liam. 20 09. "Telstra, Unions Agree on Bargaining Principles.” ZDNet.com.au. July 1. http:www.zdnet.com.au/news/communications / soa/Telstra-unions-agree-on-bargaining-principles/0.130061791.339297183.00.htm (accessed July 13, 2009).

Van Kranenburg, Hans L., and John Hagedoorn. 2008. "Strategic Focus of Incumbents in the European Telecommunications Industry: The Cases of BT, Deutsche Telekom and KPN." Telecommunications Policy, Vol. 32, No. 2, pp. 116-30.

Van Wanrooy, Brigid, Sarah Oxenbridge, John Buchanan, and Michelle Jakubauskas. 2007. "Australia@ Work." Workplace Research Centre at University of Sydney.

Vickerstaff, Sarah A., and John E.M. Thirkell. 2000. "Instrumental Rationality and European Integration: Transfer or Avoidance?" European Journal of Industrial Relations, Vol. 6, No. 2, pp. 237-51.

Whittington, Richard. 1988. "Environmental Structure and Theories of Strategic Choice." Journal of Management Studies, Vol. 25, No. 6, pp. 521-36.

Williamson, Oliver E. 1991. "Strategizing, Economizing, and Economic Organization." Strategic Management Journal, Vol. 12, No. S2, pp. 75-94. 1996. The Mechanisms of Governance. Oxford: Oxford University Press. 
Copyright of Industrial \& Labor Relations Review is the property of Cornell University and its content may not be copied or emailed to multiple sites or posted to a listserv without the copyright holder's express written permission. However, users may print, download, or email articles for individual use. 